\title{
The Influence of Compensation, Organizational Climate, and Work Commitment on the Performance of the Employees
}

\author{
Hudori $^{1}$, Eliana Sari ${ }^{2}$, Matin $^{3}$ \\ \{bobohhudori@gmail.com ${ }^{1}$, elianasari@unj.ac.id ${ }^{2}$, Matin.unj@gmail.com ${ }^{3}$ \} \\ Universitas Negeri Jakarta, Indonesia ${ }^{1,2,3}$
}

\begin{abstract}
This study aimed to determine the effects of compensation, organizational climate, and work commitment on the performance of the employees of the Regional Office of The Department of Education and Culture in Banten Province. The research used the quantitative approach with the survey method. To analyze the effects of exogenous variables on the endogenous variables, the path analysis was used. As for respondents, samples of 66 employees were taken. The result of the research indicated that (1) compensation hada positive direct influence on the performance of the employees, (2) organizational climate had a positive direct influence on the performance of the employees, (3) work commitment had a positive direct influence on the performance of the employee, (4) compensation had a positive direct influence on work commitment, and (5) organizational climate had a positive direct influence on the performance of the employees. Thus, improving employees' performance can be done with increased compensation, good organizational climate, and work commitment.
\end{abstract}

Keywords: Employees, Performance, Compensation, Organizational Climate, and Work Commitment

\section{Introduction}

Up to now, bureaucracy in Indonesia is still problematic and have not been able to meet the expectations of the community. The undisciplined nature, corruption, collusion, nepotism, and discrimination are still regarded as the behaviors of the bureaucratic system. The low performance of government apparatus resources is increasingly visible in the public service sector. Therefore, bureaucratic reform should be carried out at all levels of governments from the central government to the governments of subnational levels.

Performance is a concept that has been widely discussed in various literature, such as in the field of human resource management, organizational behavior, and psychology. One concept of performance is put forward by Landy and Conte (2013:157): "job performance is actions or behaviors, relevant to the organization's goals, measured in terms of each individual's 
proficiency. " In this case, performance means actions or behaviors that are relevant to achieve the organizational goals as measured by each individual.

In an effort to see the performance of a person, an assessment or performance evaluation is usually performed. Schemerhorn (2012:217) states that performance appraisal is a process of formally evaluating performance and providing feedback to job holders. Performance appraisal is a formal process of assessment of employees by the organization that can provide feedback to the executor.

In many literatures, compensation is also called a reward. This is reflected in the concept described by Deb (2009:18), "compensation refers to the set of rewards that organizations provide to individuals in return for their willingness to perform various jobs and tasks within the organization." Compensation is a set of rewards the organization provides to individuals in return for their willingness to perform various jobs and tasks within the organization.

Organizational climate is related to the internal condition of the organization that survives relatively long, as noted by Lussier (2017:384), "organizational climate is the relatively enduring quality of the internal environment of the organization as perceived by its members." Organizational climate is a relatively lasting quality of the internal environment of the organization as perceived by its members.

Ivancevich, Konopaske, and Matteson (2014:554) also revealed about the organizational climate, that is "organizational climate is a set of properties of the work environment, perceived, directly or indirectly by the employees, that assumed to be a major force in influencing employee behavior."

Conceptually, commitment leads more to the power of one's mind; as put forward by Klein, Becker, and Meyer (2009:40), "commitment as an internal force (mindset) that binds individual to a target (social or nonsocial) and/or to a course of action of relevance to that target." Commitment is an internal force (mindset) that binds individuals to targets (social or non-social) and/or toward actions relevant to the target.

Organizational commitment means bonding and loyalty, which is the relative strength of the identification with the individual and his involvement with the organization. Such relative strengths include three things: (1) a strong desire to maintain membership in the organization, (2) a strong belief and acceptance of organizational values and objectives, and (3) a willingness to make great efforts on behalf of the organization. Work commitment can be synthesized as the level of responsibility of the employees on the job, which becomes their main task and function and their involvement in an organization as measured by the following indicators: work spirit, obedience to the rules, participation in agency goals, moral ties, and well completion of the task.

\section{Research Methodology}

The method of the study belongs to a quantitative research with survey and a casual approach is applied as the research method .The total population of the research is all workers of the Regional Office of the Department of Education and Culture in Banten Province, while the affordable population as a sampling frame was the structural employees of the Regional Office of the Department of Education and Culture in Banten Province as many as 153 people. The number 
of samples was determined based on the Slovin formula which was as many as 66 peoples, and data collection is done through tests and questionnaires using a Likert scale. (see at https://osf.io/c7wkb/ )

\section{Results and Discussion}

The data relations between variables have a significant correlation coefficient $(\mathrm{p}<0.05)$. It can be said that the inter-variables have a significant relationship, so it is feasible to proceed at the stage of model analysis.

\subsection{The Calculation of Line Coefficients}

After the data obtained from all over Banten Province is processed and analyzed through various required tests, the next step in testing the causality model is to conduct path analysis. Based on the theoretically formed causal model, we obtained the path analysis diagram and calculated the coefficient values of each path.

\section{a. Relationship Model of Between-Variable Paths}

The relationship model of between-variables of one endogenous variable, namely: employee performance $(\mathrm{Y})$, and four exogenous variables, namely work commitment $\left(\mathrm{X}_{3}\right)$, Organizational climate $\left(\mathrm{X}_{2}\right)$, and Compensation $\left(\mathrm{X}_{1}\right)$, and one residual variable that is $\varepsilon_{\mathrm{y}}$. Based on this relation, the path model is as follows : $Y=\beta_{\mathrm{y} 1} \mathrm{X}_{1}+\beta_{\mathrm{y} 2} \mathrm{X}_{2}+\beta_{\mathrm{y} 3} \mathrm{X}_{3}+\varepsilon_{\mathrm{y}}$.

Based on the results of the path analysis the coefficient of compensation path $\left(\mathrm{X}_{1}\right)$ on the performance of employee service $(\mathrm{Y})$ is $\rho_{\mathrm{Y} 1}=0.178\left(\mathrm{t}_{\text {count }}=.1 .766 ; \mathrm{p}<0.05\right)$, which is statistically significant, so $\mathrm{H}_{0}$ is rejected. The coefficient of organizational climate path $\left(\mathrm{X}_{2}\right)$ on service performance $(\mathrm{Y})$ is $\rho_{\mathrm{Y} 2}=0.588\left(\mathrm{t}_{\text {count }}=5.486\right.$; $\left.\mathrm{p}<0.05\right)$, ), which is statistically significant, so $\mathrm{H}_{0}$ is rejected. The coefficient of work commitment path $\left(\mathrm{X}_{3}\right)$ on service performance of employees $(\mathrm{Y})$ is $\rho_{Y 3}=0.256\left(t_{\text {count }}=3.943\right)$, sig $=0.00<\alpha=005$, which is statistically significant, so $\mathrm{H}_{0}$ is rejected.

On the basis of these calculations, the empirical causal relationship frame work of variables $\mathrm{X}_{1}, \mathrm{X}_{2}$, and $\mathrm{X}_{3}$ on $\mathrm{Y}$ on substructure-1 is as follows: $\hat{\mathrm{Y}}=0.178 \mathrm{X}_{1}+0.588 \mathrm{X}_{2}+0.238 \mathrm{X}_{3}+$ 0.219 while $\mathrm{R}^{2} \mathrm{YX} 321=0.954$. The magnitude of the influence of other variables outside $\mathrm{X}_{1}, \mathrm{X}_{2}$, and $\mathrm{X}_{3}$ on $\mathrm{Y}$ isError! Reference source not found. $=0.219$.

Based on the overall structural calculation, the structural model that can be presented includes the amount of influence on the variables that can be seen in the figure below. 


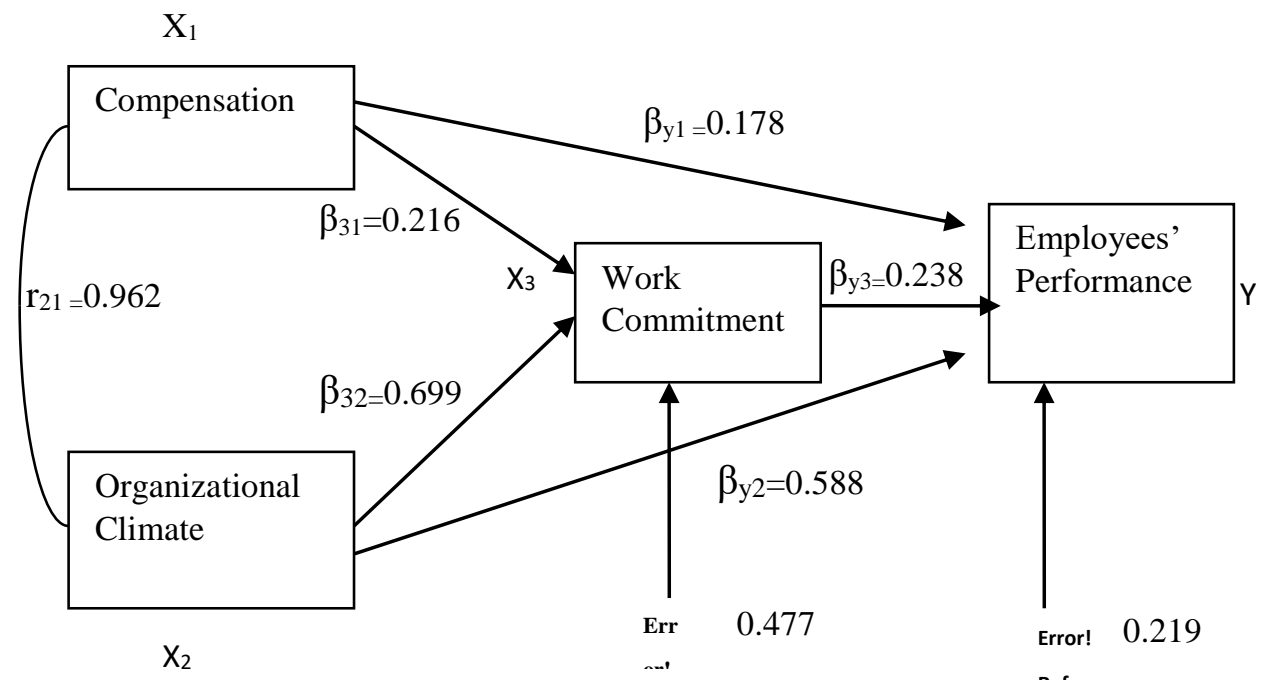

Fig 3. The Model of Empirical Causal Relationships between $X_{1}, X_{2}, X_{3}$ on $Y$

\section{Discussion}

The results of research on the influence of compensation, organizational climate, and work commitment on the performance of the employees can be described as follows:

\subsection{The Influence of Compensation $\left(X_{1}\right)$ on The Performance of the employees of the Regional Office of the Department of Education and Culture in Banten Province (Y)}

From the result of the research, the influence with the path coefficient $\beta y 1=0.178$ was obtained. This figure shows the direct influence of the compensation variable on the performance of employees' service as of $17.8 \%$. This pattern is appropriate with Hoffman and Lyon's (2014) research on whether salaries can improve job performance, and, statistically, higher salaries relate to employees' performance and competitiveness. It is further explained that increasing salaries, although economically small, respond to improving the performance of workers of politicians.

The above gives an idea that the form of compensation is needed as a form of employees' empowerment. Compensation is not a basic salary but a form of incentive on the daily work to eliminate customer perceived deviations. Therefore, compensation has a positive direct effect in improving the performance of employees' services.

\subsection{The Influence of Organizational Climate $\left(\mathrm{X}_{2}\right)$ on Employees' Performance $(\mathrm{Y})$}

In this study, the magnitude of the direct influence of organizational climate on employee performance contributed was $58.8 \%$ and the path coefficient $\beta y 2$ was 0.588 . These results show that the organizational climate had a real contribution in improving employees' performance. This, 
according to Gracia, Cifre, and Grau (2010), with structural equation modeling, shows that performance can be predicted based on organizational climate, and service behavior can be predicted based on customer perceptions. This provides support to the research that the organizational climate had a direct influence on performance.

\subsection{The Influence of Work Commitment (X3) on Service Performance of Employees (Y)}

The formation of work commitment is strongly influenced by certain variables. But in terms of the performance of employees, work commitment has a strongdirect influence on the quality of work. Commitment is a form of employees' engagement, both emotionally and culturally, and their competence provides a degree of trust in the institution. The higher the level of trust in the institution, the more considerable will be the increase in the employees' performance.

In this research, the work commitment variable had the path coefficient of $\beta_{\mathrm{y} 3} 0.238$, or it had an influence equal to $23.8 \%$. This pattern is based on a form of the commitment integrity to the organization. Commitment clusters can be distinguished between normative commitment, affective commitment, and continual commitment. Work commitment in this research belongs to the categories of normative commitment; the size of commitment is based on the effectiveness of the task and the principal functions of the employees.

\subsection{The Influence of Compensation $\left(\mathrm{X}_{1}\right)$ on Work Commitment $\left(\mathrm{X}_{3}\right)$}

The existence of the work commitment variable is also fundamentally determined by the form of compensation provided. Standardized, orderly, non-discriminatory, and tiered compensation types provide a positive influence for an increased work commitment. The form of influence of compensation on work commitment is a form of indirect influence on employee service performance.

The magnitude of the path coefficient of the compensation variable on work commitment gave the number of $\beta 310.216$ or the influence of $21.6 \%$.In some references, it is shown that the compensation of informal income form is obtained directly from customers due to the effect of service on certain personnel. Does this include a form of encouragement for work commitment? Brian Miller conducted comparative research on personnel who are not compensated in the form of "Tips" with personnel who get "Tips," and it appears that there is no effect on work commitment. This shows that compensation shows a weak relationship in the formation of work commitment .

\subsection{The Influence of Organizational Climate $\left(X_{2}\right)$ on Work Commitment $\left(X_{3}\right)$}

The influence of organizational climate on work commitment is determined by the existence of indicators of relationships among colleagues, which are mutually bound, in and between work units to form a bond together to be loyal to the institution. This is what shapes the effect on work commitment. This condition determines the influence of organizational climate that directly influences the performance of employees' services through the conditions of work commitment.

The magnitude of the path coefficient of organizational climate variable on work commitment was $\beta 320.699$, or its influence was equal to $69.9 \%$. It is clear that the organizational climate 
contributes significantly to affecting work commitment. Fauziah's et al. (2010) study on the influence of organizational climate on commitment shows that an effective, continuous, and normative dimension organizational climate gives positive influence. This supports this research that effective relevance greatly determines employees to commit to their work.

The influence of indirect compensation variable indirectly contributes more on employees' service performance through work commitment variable, which was equal to $\left(\beta_{31} 0.216+\beta_{\mathrm{y} 3}\right.$ $0.238)=0.451$ compared to the path coefficient of direct influence of compensation to employees' performance that was $\beta_{\mathrm{y} 1} 0.178$.

Likewise, with the organizational climate variables on the performance of service employees, the direct relationship had a lower effect $\left(\beta_{\mathrm{y} 2}=0.588\right)$ compared with the indirect influence of organizational climate variables on employee performance through work commitment variable of $\left(\beta_{32} 0.699+\beta_{\mathrm{y} 3} 0.238\right)=0.937$.

The compensation variables and organizational climatic variables are potential to build work commitment and measurably will have a positive influence on the achievement of employees' service performance.

\section{Reference}

[1] Armstrong,Michael. A Handbook of Human Resource Management Practice.London, Philadelphia: Kogan Page, (2012)

[3] Gray,Roderic,A Climate of Success: Creating the Right Organization Climate for High Lussier, Robert N. Human Relations in Organizations. New York: McGraw-Hill Education, (2017)

[4] Hidayat, Muchtar. AnalisisKomitmen (Affective, Continuance dan Normative) Terhadap Kinerja Pelayanan Pengesahan STNK Kendaraan Bermotor (StudiEmpirispada Kantor bersamaSamsat di Propinsi Kalimantan Timur) . Jurnal Manajemen dan Kewirausahaan, vol.12, no. 1, maret 2010: 11-23

[5] Hoffman, Mitchell and Elizabeth Lyons., Do higher salary lead to higher performance? Evidence from state politicians. July, 2014

Ivancevich, J. M. R. Konopaskedan M.T. Matteson, Organizational Behaviour and Management. New York: McGraw-Hill/Irwin, (2014)

[6] Lussier, Robert N. Human Relations in Organizations. New York: McGraw-Hill Education, (2017)

[7] Medina,Roberto G. Personnel and Human Resources Management. Manila: REX Book Store, (2006)

[8] Meyer, J.P. and Allen, N.J., 1991, "A three component conceptualisation of organisational commitment", Human Resource Managemen Review,

[9] Peng,Kelly Z., Hang-Yue Ngo, Junqi Shi, dan Chi-Sum Wong, "Gender Differences in the Work Commitment of Chinese Workers: An Investigation of Two Alternative Explanations," Journal of World Business, Vol. 44, 2009, hh. 323-335.

[10] Noordin, Fauziah et al., Organizational climate and its influence on organizational commitment. Int'1 Business and Economics Research Journal, February, 2

[11] Pinder., Craig C. Work Motivation in Organizational Behavior. New York: Psychology Press, (2008)

[12] Tapomoy, Deb.Compensation Management. New Delhi: Excel Books, (2009)

[14] Miller, Brian,Compensating Restaurant Employee Through Tips: an Antecedent for Organizational Commitment?, Arcticle, impress, (2010) 